\title{
Ecological responses of three urban watercourse stretches after implementation of one-off recovering interventions: an integrated
} \section{assessment}

Kristiane Primo ${ }^{1}$, Alexandre da Silva ${ }^{1}$, Rosiane e Silva ${ }^{1}$, Beatriz Olimpio ${ }^{1}$, Gabriela Silva ${ }^{1}$, and Ana Paula Silva ${ }^{2}$

${ }^{1}$ UNESP

${ }^{2}$ Federal University of Itajubá

April 8, 2021

\begin{abstract}
Faced with the anthropic activities of urban streams stretches through rectification with concrete, there is a concern about the modifications of the aquatic habitats and consequent ecological damages to the ecosystems. Based on biophilic engineering, there is a great opportunity to idealize and test interventions to revitalize such hampered ecosystems. Hence, we verified the performance of biological and organic factors, after the implementation of one-off interventions in three rivers using biophilic handmade materials and structural elements in their fixation. We carried out the project in urban stretches of concrete bed streams, located in Sorocaba-SP, Southeast of Brazil. In two years, we conducted biweekly in situ and laboratory measurements to characterize the study sites, idealize, scale, implement the projects, and, evaluate the ecological responses of the implementations. We collected sampling in two points: upstream and downstream interventions. We evaluated the performance of the interventions through the analysis of SWOT (Strengths, Weaknesses, Opportunities, and Threats) factors and by using the Analytic Hierarchy Process (AHP). We presented the results through a decision-making matrix for stakeholders, which indicated that our ideas are of low cost and easy to implement. Then, we got the following scenario of SWOT priorities: opportunity $(58.55 \%)$, strength $(24.71 \%)$, threat $(10.74 \%)$, and weakness $(6.00 \%)$. They demand constant efforts for maintenances and they need adjustments to a better understood by residents and the watershed management. We concluded that the strengths observed in the project turn our idea replicable in any part because it attaches the idea of caring about the environment through biophilic techniques, and the weaknesses are liable to modifications (improvements) in future projects that consider such proposal.
\end{abstract}

\section{Hosted file}

manuscript_kristiane.pdf available at https://authorea.com/users/406507/articles/517134ecological-responses-of-three-urban-watercourse-stretches-after-implementation-of-oneoff-recovering-interventions-an-integrated-assessment

\begin{tabular}{lcc}
\multirow{2}{*}{ External Factors } & Strengths (S) & Weaknesses (W) \\
& Positive/Positive criterion & Positive/Negative criterion \\
\hline Opportunities (O) & Negative/Positive criterion & Negative/Negative criterion \\
Threats $(\mathrm{T})$ & &
\end{tabular}



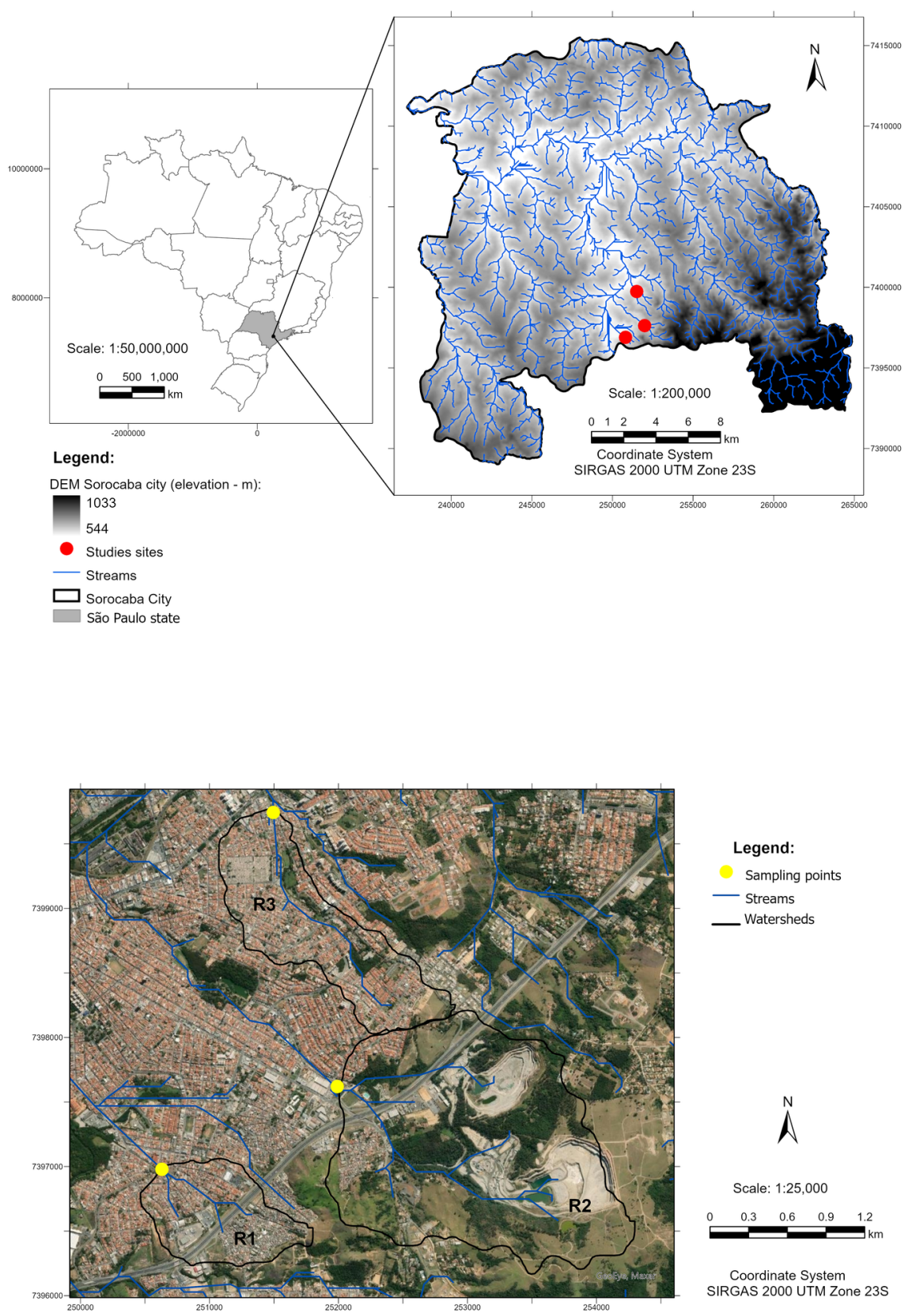

Scale: $1: 25,000$

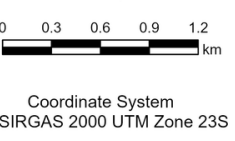



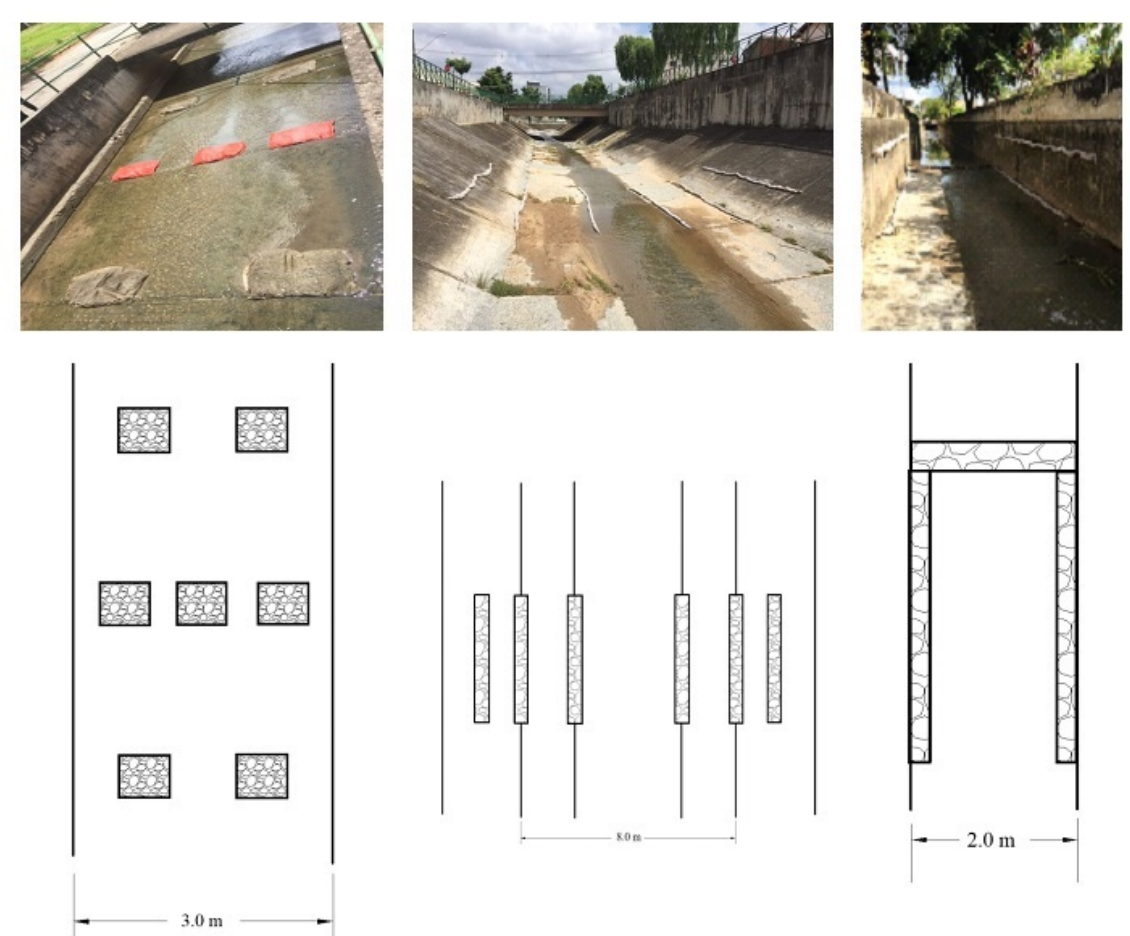

(a)

(b)

(c) 


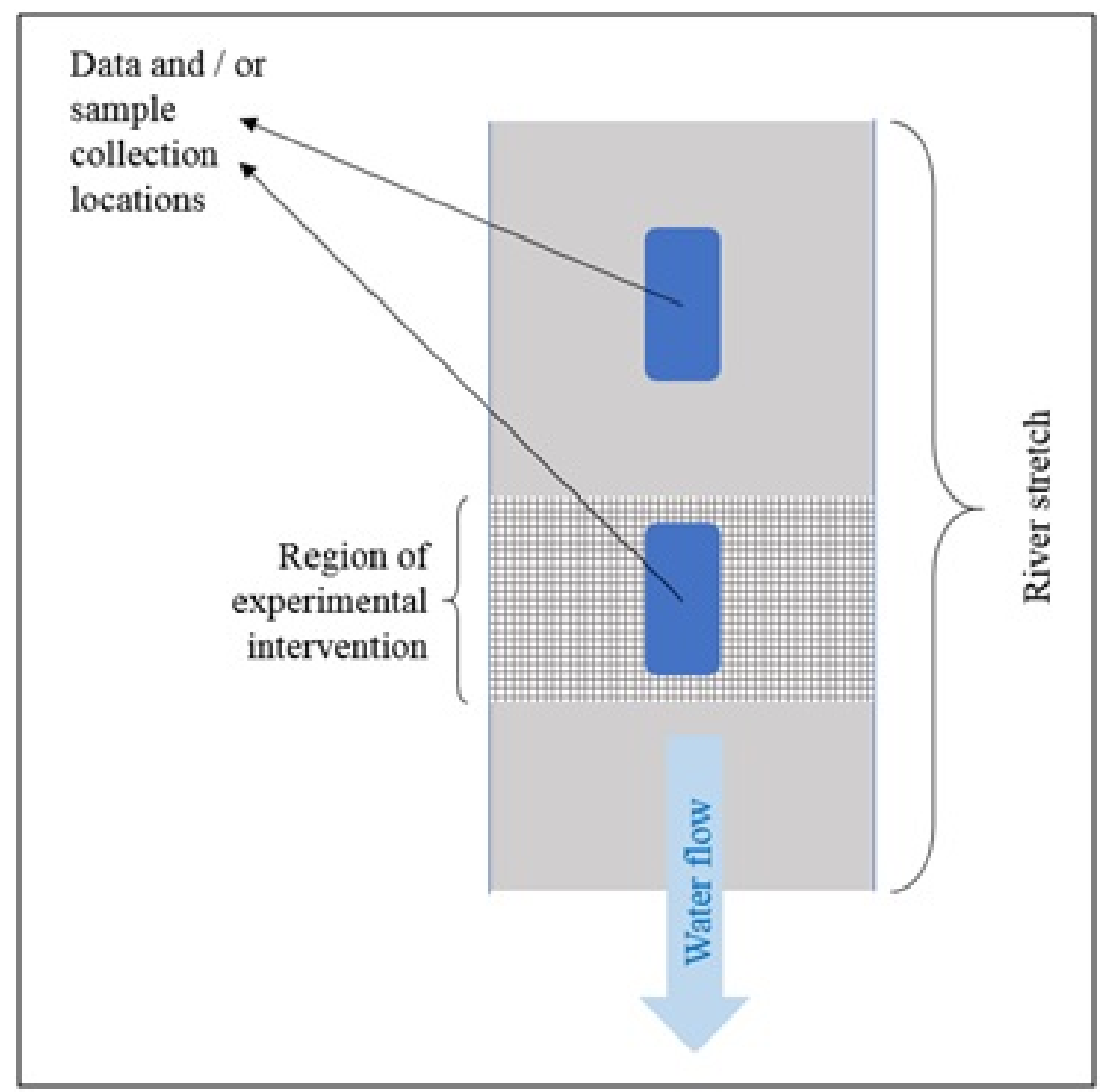




\begin{tabular}{|c|c|}
\hline & \\
\hline $\begin{array}{l}\text { Total organic carbon (TOC) } \\
\text { of the sediment }\end{array}$ & $\begin{array}{l}\text { We collected and transported the samples of sediments to the laboratory } \\
\text { (approximately } 1 \mathrm{~L} \text { each sample), and after remaining in an oven (at } 100^{\circ} \mathrm{C} \text { ) and } \\
\text { subsequently in a muffle (at } 550^{\circ} \mathrm{C} \text { ) and desiccation, we calculated the organic } \\
\text { carbon content through the equation }(1) \text { ) } \\
\qquad \mathrm{C}=\frac{\mathrm{P}_{1}-\mathrm{P}_{2} \cdot 100}{\mathrm{M}} \cdot \mathrm{f} \\
\text { Where: } \mathrm{C} \text { : organic carbon content of the sediment (\%); } \mathrm{P}_{1} \text { : dried mass after oven (g); } \\
\mathrm{P}_{2} \text { : dried mass after muffling incineration (g); M: initial sample mass (g); } \mathrm{f} \\
\text { conversion factor: the amount of organic matter to organic carbon content. This } \\
\text { coefficient assumes that organic matter contains } 58 \% \text { of organic carbon } \\
\text { (Aleksandrova and Naidenova, } 1976 \text { apud Jankauskas et al., 2006). }\end{array}$ \\
\hline $\begin{array}{l}\text { Biochemical oxygen demand } \\
\text { (BOD) }\end{array}$ & 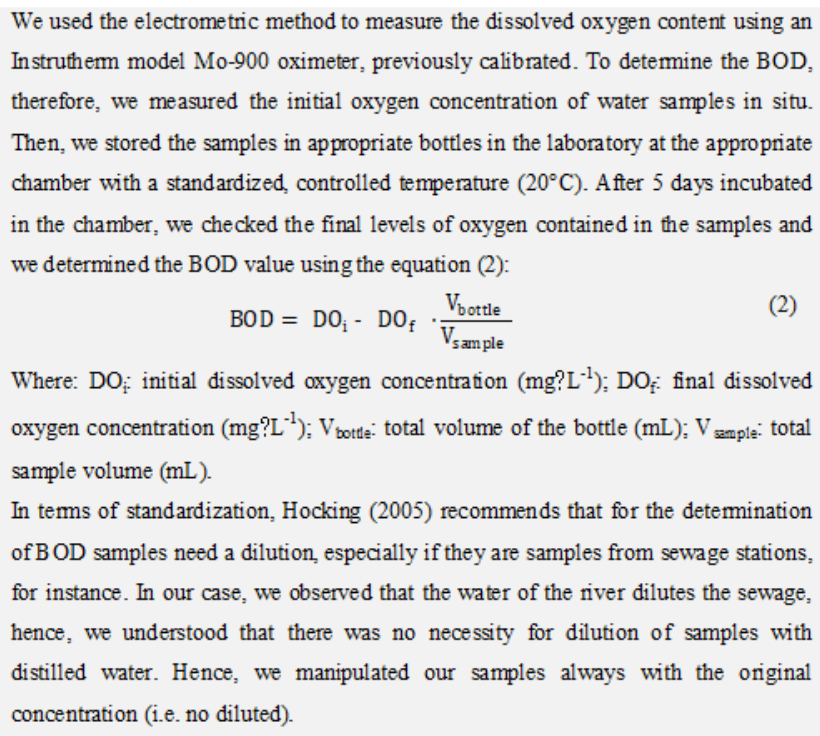 \\
\hline Invertebrate animals & $\begin{array}{l}\text { We collected invertebrate animals with a Surber sampler. We positioned the sampler } \\
\text { always counter to the current and always at the same time of the day, which made it } \\
\text { possible to establish a homogeneity in the development of the specimens, which } \\
\text { included several stages of development immatures (larvae and pupae). Initially, we } \\
\text { carefully removed the larvae from the Suber and placed them in a flask with water. In } \\
\text { the laboratory, we removed the larvae from the water with the aid of a small plastic } \\
\text { sieve, carefully dried them witha paper towel, and quantified them. }\end{array}$ \\
\hline $\begin{array}{l}\text { Emergence and development } \\
\text { of vascular plants }\end{array}$ & $\begin{array}{l}\text { Following the recommendations of Gann et al. (2019), we took photographs } \\
\text { throughout the project period to evidence the ecological responses and the possible } \\
\text { achievement of our objectives for the interested parties. We took the pictures monthly } \\
\text { as a record and analysis of specimen development in the streams. Additionally, we } \\
\text { collected samples of the plants and delivered them to plants taxonomists for } \\
\text { identification of the species. }\end{array}$ \\
\hline
\end{tabular}




\begin{tabular}{|c|c|c|c|c|}
\hline \multicolumn{2}{|l|}{ Property } & R1 & R2 & R3 \\
\hline \multicolumn{2}{|l|}{ Area $\left(\mathrm{km}^{2}\right)$} & 0.73 & 3.30 & 1.25 \\
\hline \multicolumn{2}{|l|}{ Perimeter $(\mathrm{km})$} & 3.60 & 7.68 & 5.83 \\
\hline \multicolumn{2}{|c|}{ Highest and lowest altimetry, and topographic range (meters) } & $660-544=116$ & $729-580=149$ & $620-560=60$ \\
\hline \multicolumn{2}{|l|}{ Average slope $\left(\mathrm{m} \cdot \mathrm{m}^{-1}\right)$} & 4.7 & 43 & 2.6 \\
\hline \multicolumn{2}{|c|}{ Number of headwaters and hierarchical order (in parenthesis) } & $4(2)$ & $13(2)$ & $5(3)$ \\
\hline \multirow[t]{5}{*}{ Land cover categories (percentages) } & Natural Remnant Vegetation & 9.9 & 13.5 & 11.2 \\
\hline & Pasture & 5.8 & 17.9 & 6.9 \\
\hline & Uncovered soil & 9.7 & 8.9 & 0.1 \\
\hline & Urbanized sites & 74.6 & 37.6 & 81.7 \\
\hline & Mining & 0.0 & 221 & 0.0 \\
\hline
\end{tabular}

\begin{tabular}{|c|c|c|c|c|c|c|c|}
\hline \multirow{2}{*}{\multicolumn{2}{|c|}{ Statistical tests }} & \multicolumn{3}{|c|}{ TOC of the sediment $(\%)$} & \multicolumn{3}{|c|}{ BOD of the water $\left(\mathrm{mg} \mathrm{L}^{-1}\right)$} \\
\hline & & Rl & $\mathbf{R} 2$ & R3 & Rl & $\mathbf{R 2}$ & R3 \\
\hline Shapiro-Wilk test & & $p<0.05$ & $p>0.05$ & $p<0.05$ & $p<0.05$ & $p<0.05$ & $p<0.05$ \\
\hline \multicolumn{8}{|l|}{ Hypothesis testing } \\
\hline & $p$ (two-tailed) & $0.1701^{\mathrm{a}}$ & $0.0774^{b}$ & $0.5277^{\mathrm{a}}$ & $0.0571^{\mathrm{a}}$ & $0.6529^{\mathrm{a}}$ & $0.3088^{\mathrm{a}}$ \\
\hline & $p$ (one-tailed) & $0.0851^{\mathrm{a}}$ & $0.0387^{b}$ & $0.2639^{\mathrm{a}}$ & $0.0285^{\mathrm{a}}$ & $0.3265^{\mathrm{a}}$ & $0.1544^{\mathrm{a}}$ \\
\hline
\end{tabular}

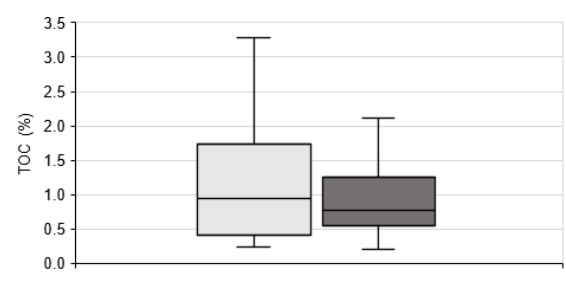

口Upstream $\square$ Intervention

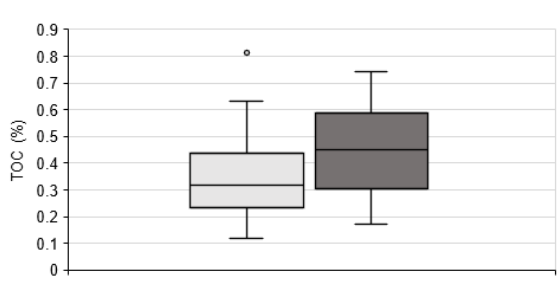

口Upstream $\square$ Intervention

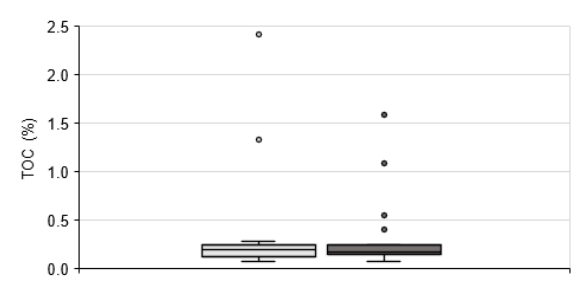

口Upstream $\square$ Intervention

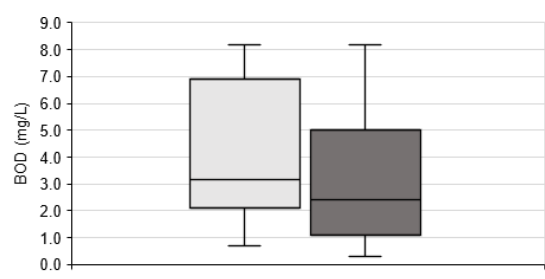

口Upstream $\square$ Intervention

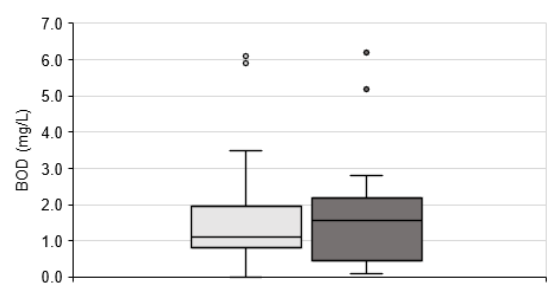

$\square$ Upstream $\square$ Intervention

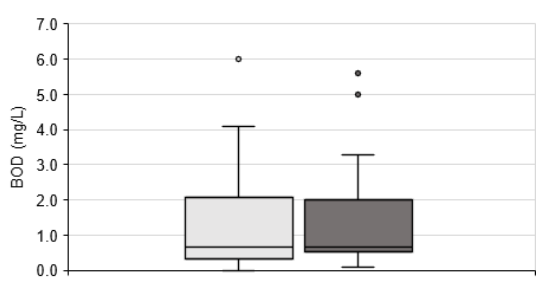

口Upstream $\square$ Intervation 


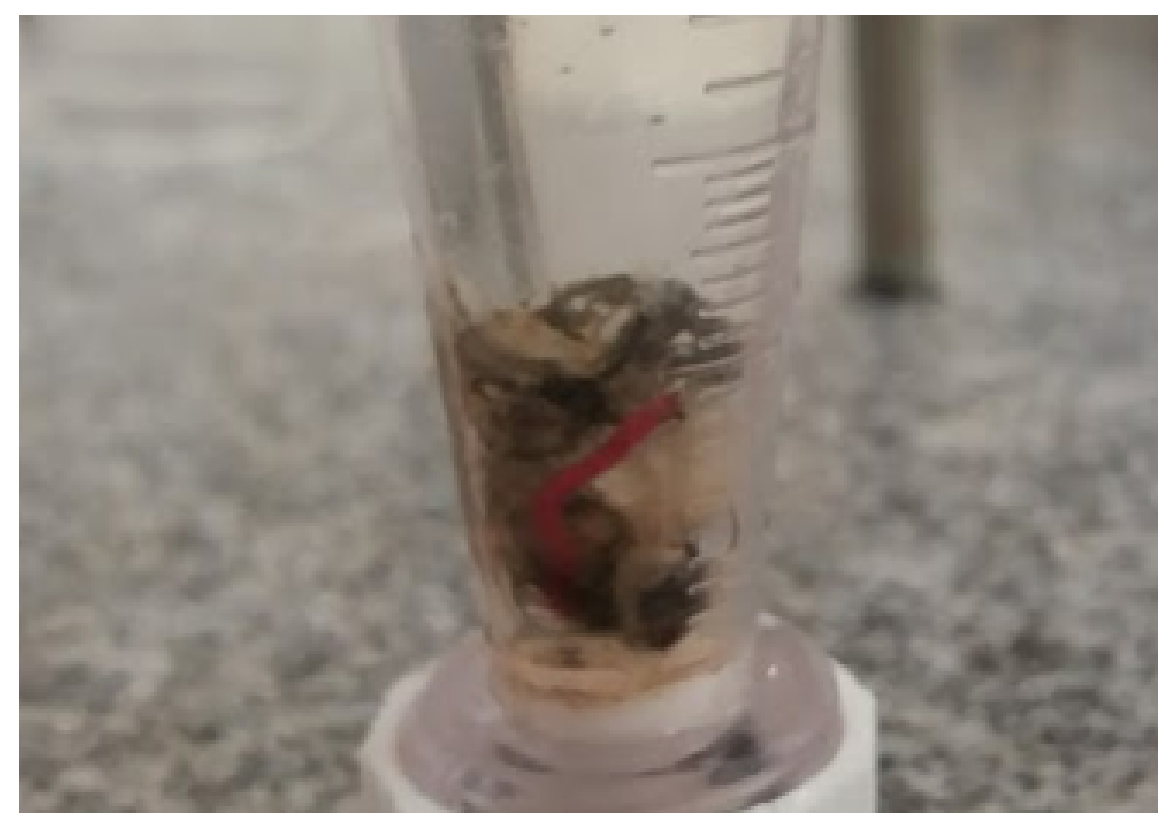

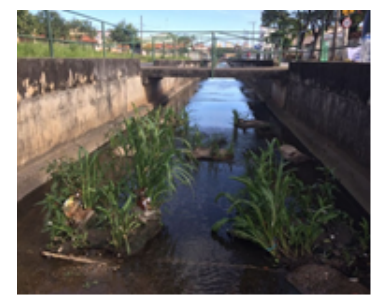

(a)

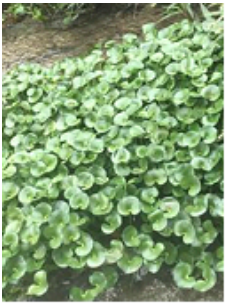

(a)

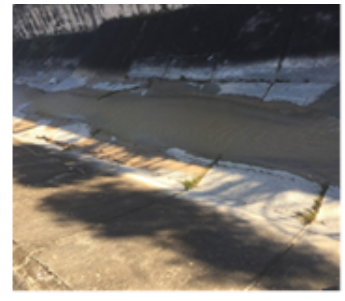

(b)

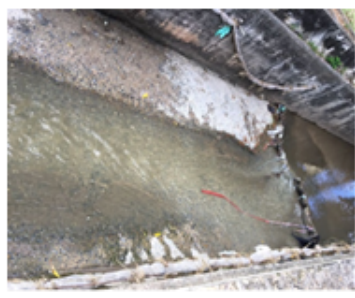

(c)

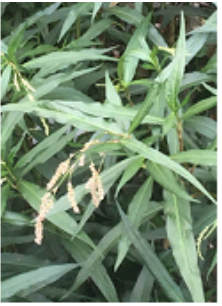

(b)

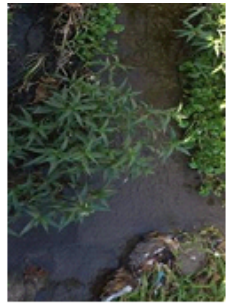

(c)

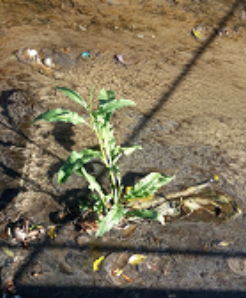

(d)

\begin{tabular}{|c|c|c|}
\hline & Strengths (S) & Weaknesses (W) \\
\hline \multirow{4}{*}{$\begin{array}{l}\text { Internal } \\
\text { factors }\end{array}$} & Low-cost projects (S1) & Maintenance neces sity (W1) \\
\hline & Easy implementation and execution (S2) & Shortage of people minimally trained to \\
\hline & $\begin{array}{l}\text { The fast growth of spontaneous } \\
\text { vegetation (S3) }\end{array}$ & $\begin{array}{l}\text { execute successfully the tasks (W2) } \\
\text { Sewage indicators species in the water (W3) }\end{array}$ \\
\hline & Opportunities (O) & Threats (T) \\
\hline $\begin{array}{l}\text { External } \\
\text { factors }\end{array}$ & $\begin{array}{l}\text { Using of recycled materials (O1) } \\
\text { Project visibility and dissemination for } \\
\text { the population (O2) } \\
\text { Water quality improvement with simple } \\
\text { work (O3) }\end{array}$ & $\begin{array}{l}\text { The vulnerability of biological invasions } \\
\text { (T1) } \\
\text { Risk of work damage by the local } \\
\text { misunderstoodpopulation (T2) } \\
\text { Risk of loss of work due to the very } \\
\text { aggressive weather (T3) }\end{array}$ \\
\hline
\end{tabular}




\begin{tabular}{|c|c|c|c|c|c|}
\hline SWOT group & $\begin{array}{l}\text { Group } \\
\text { priorit } \\
\text { y }(\%)\end{array}$ & $\begin{array}{c}\mathrm{CR}^{1} \text { of } \\
\text { the } \\
\text { group }\end{array}$ & SWOT factors & $\begin{array}{l}\text { The } \\
\text { priority of } \\
\text { the factor } \\
\text { within the } \\
\text { group } \\
(\%)^{2}\end{array}$ & $\begin{array}{c}\text { Overall } \\
\text { priority } \\
\text { of the } \\
\text { factor } \\
(\%)\end{array}$ \\
\hline \multirow{3}{*}{ Strengths } & \multirow{3}{*}{24.71} & \multirow{3}{*}{0.008} & Low-cost projects (S1) & $\underline{53.96}$ & 13.34 \\
\hline & & & $\begin{array}{l}\text { Easy implementation and execution } \\
\text { (S2) }\end{array}$ & 29.70 & 7.34 \\
\hline & & & $\begin{array}{l}\text { The fast growth of spontaneous } \\
\text { vegetation (S3) }\end{array}$ & 16.34 & 4.04 \\
\hline \multirow{3}{*}{ Weaknesses } & \multirow{3}{*}{6.00} & \multirow{3}{*}{0.046} & Maintenance necessity (W1) & 18.40 & 1.10 \\
\hline & & & $\begin{array}{l}\text { Shortage of people minimally trained } \\
\text { to execute succes fully the tasks } \\
\text { (W2) }\end{array}$ & 58.42 & 3.50 \\
\hline & & & $\begin{array}{l}\text { Sewage indicators species in the } \\
\text { water (W3) }\end{array}$ & 23.18 & 1.39 \\
\hline \multirow{3}{*}{ Opportunities } & \multirow{3}{*}{58.55} & \multirow{3}{*}{0.019} & Using of recycled materials (O1) & 13.12 & 7.68 \\
\hline & & & $\begin{array}{l}\text { Project visibility and dissemination } \\
\text { for the population }(\mathrm{O} 2)\end{array}$ & 7.60 & 4.45 \\
\hline & & & $\begin{array}{l}\text { Water quality improvement with } \\
\text { simple work (O3) }\end{array}$ & $\underline{79.28}$ & 46.41 \\
\hline \multirow{3}{*}{ Threats } & \multirow{3}{*}{10.74} & \multirow{3}{*}{0.002} & Biological invasions (T1) & 9.77 & 1.05 \\
\hline & & & $\begin{array}{l}\text { Risk of work damage by the local } \\
\text { misunderstood popul ation (T2) }\end{array}$ & 18.70 & 2.01 \\
\hline & & & $\begin{array}{l}\text { Risk of loss of work due to very } \\
\text { aggressive weather (T3) }\end{array}$ & 71.53 & 7.68 \\
\hline
\end{tabular}

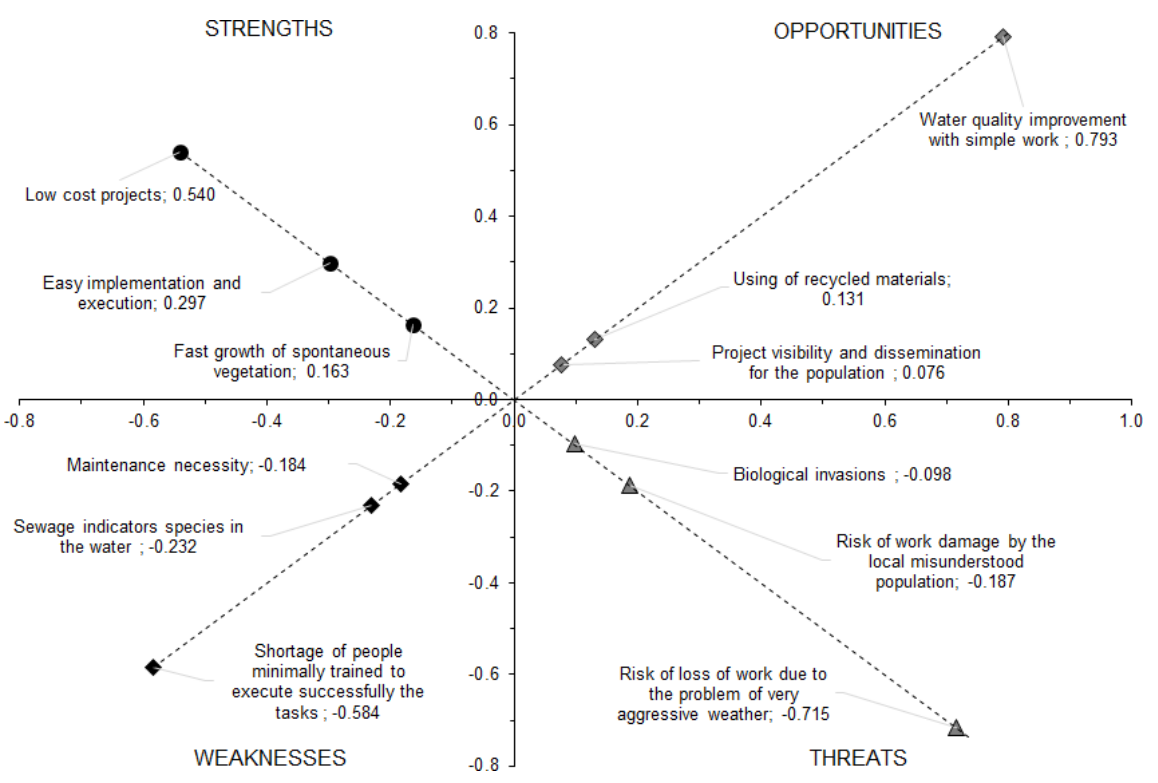




\begin{tabular}{|c|c|c|}
\hline & Strength (S) & Weakness (W) \\
\hline Opportunity (O) & $\begin{array}{l}\text { Improve water quality and urban } \\
\text { landscape, in streams previously } \\
\text { investigated with potential for } \\
\text { revitalization, throughout low-cost and } \\
\text { easy execution bioengineering works. }\end{array}$ & $\begin{array}{l}\text { Disseminate the knowledge of the } \\
\text { river restoration subject through the } \\
\text { publication of works for the academic } \\
\text { environment recognition and arouse the } \\
\text { interest of investors and public managers } \\
\text { in this theme. }\end{array}$ \\
\hline Threat (T) & $\begin{array}{l}\text { More involvement of the } \\
\text { population, with the issuing of alerts to } \\
\text { the project monitors, especially after } \\
\text { events of intense rain and fast response } \\
\text { of the streams water levels. }\end{array}$ & $\begin{array}{l}\text { We recommend a previous study of } \\
\text { the sediment dynamics of the streams, } \\
\text { verification of the use and occupation of } \\
\text { the soil, and flow regime, for a better } \\
\text { choice of the type of work and place of } \\
\text { implementation, foreseeing the } \\
\text { maintenance reduction. }\end{array}$ \\
\hline
\end{tabular}

